INTERNATIONAL JOURNAL OF RESEARCHES IN BIOSCIENCES, AGRICULTURE AND TECHNOLOGY

(C) VISHWASHANTI MULTIPURPOSE SOCIETY (Global Peace Multipurpose Society) R. No. MH-659/13(N) wWw.vmsindia.org

\title{
CONPREHENSIVE STUDY ON FLORAL VARIATIONS OF MALVACEAE FAMILY
}

\author{
Ashwini. B. Phokmare \\ Department of Botany, SGB Amravati University, Amravati. \\ ashuphokmare@gmail.com
}

\begin{abstract}
:
In the present study, an attempt has been made to differentiate floral parts in Malvaceae family. We have taken 6 plants from Malvaceae family. It is noted that variations in the morphological characters of plant may be due to the fact that most of the species are growing naturally in their habitat. Characters contributed greatly in differentiating individual genus and species from same family i.e. Malvaceae for each other.

Keywords: Flora, Malvaceae, Corolla, Gynoecium, Microscopic examination, Measurement.
\end{abstract}

\section{Introduction:}

Taxonomy is the method by which scientists, conservationists, and naturalist classify and organize the vast diversity of living things on this planet in an effort to understand the evolutionary relationships between them. Prior to Linnaeus, all described species were given long, complex names that provided much more information than was needed and were clumsy to use. Linnaeus took a different approach; he reduced every single described species to a two part, Latinized name known as the "Binomial" name. Thus, through the Linnaean system a species such as the dog rose changed from long, unwieldy names such as Rosa sylvestris, Inodora seucania and Rosa sylvestra alba cum rubore, folio glabro to the shorter, easier to use Rosa cania. This facilitated the naming of species that, with the massive influx of new specimens from newly explored regions of Africa, Asia and America; also were in need of more efficient and usable system. Although trained in the field of medicine, Botany and classification were the true passions of Linnaeus and he actively explored Northern Europe and described and named hundreds of new plant species during his life time.

A flower is a functional unit concerned with sexual reproduction. A flower can be pictured as a very short stem (receptacle) which holds the components of the flowers in sequence. At the very tip of this stem, so they appear in the centre of the flower, are the female organs (gynoecium). Behind them are the male organs(the Androecium) and behind them, on the outside of the flower, are the petals and sepals.

Malvaceae: Malvaceae family comprises 88 genera and 2300 specis distributed across the world (Heywood 1978; Burkill 1997). Plants might be annual herbs (Malva sylvestris) or perennial shrubs (Hibiscus rosa-sinensis) or trees (Thespesia populnea). The members of this family have mucilaginous substance. Stellate hairs are usually present on their young parts. Flower Bracteate/ebracteate, bracteolate

or ebractiolate, pedicellate, dichlamydeo uspentamerous, complete, actinomorphic, regular, bisexual and hypogynous.

Calyx: Sepals 5, Green, gamosepalous displaying velvet aestivation.

Corolla: Petals 5, coloured, polypetalous but little fused at the base because of adhesion with stamina tube, regular and displaying twisted aestivation.

Androecium: Several stamens, filaments are fused to create a stamina tube around the style and monadelphous.

Gynoecium: Ovary superior, two several carpels but generally 5-10 carpels and syncarpous. Ovary with two to several locules.

\section{Review of Literature:}

Alqasoumi (2001) studied the species Abelmoschus esculentus L. 'Okra' which is one of the member of the Malvaceae family. It is known by many names like ladies finger, Bamyah and Bhindi. In the present study an attempt has been made to validate the claimed uses of 'Okra' Abelmoschus esculentus in liver diseases. The preventive action of ethanolic extract of 'Okra' (EEO) against liver injury was evaluated in rodent using carbon tetrachloride induced hepatotoxicity model.

Anil kumar (2012) reviewed on Hibiscus rosasinensis. Nature has been a source of medicinal agents for thousands of years and an impressive number of modern drugs have been isolated from natural sources, many based on their use in traditional medicine. The enormous flowers are usually dark red in colour and not usually fragrant. Grown in different regions of asian continent, these beautiful flowers are 
denoted by several other names such as chinarose.

Junior Cezar Muneratto and Fryxell (1985), has reported the genus Sida has been heterogeneous since its origin as botanists tended to put into Sida any member of the Malvaceae that are uniovulate and without an involucel. However, there has been a reduction in the size of the genus with the removal of many species to other genera, giving a more natu-ral and definable residual group. Fryxell (1985) subdivided this residual group into 11 sections. The aims of this study were to describe and compare the floral structure of three weedy species of Sida, namely $S$. rhombifolia L., $S$. urens L., and S. regnellii R.E. Fr.

Richmond (1957) reported observing three factors which were important in controlling the time of flowering in the cross involving Gossypium hirsutum race maraigalante, a short day photoperiodic perennial cotton. According to them the short-day photoperiodic response was under multigenic control, and, in addition to photoperiodic response maraigalante carried factors for delayed flower initiation.

\section{Material and Methods:}

Taxonomic description was worked out as per the standard key given by V.N. Naik (2005). Species identification, the plant data and characters were analysed from the flora of Maharashtra (Almeda, 2001, 1 st $^{\text {edition Volume }}$ III A and Volume IV B), Flora of Amravati district with special reference to the distribution of tree species (Dhore M.A. 2002).

Survey and Collection: The survey was aimed to collect the plant flowers belonging to the family Malvaceae in the University campus of Sant Gadge Baba Amravati University, Amravati for the study of flower variation and morphological characters. Flowers were collected and brought to the laboratory for analysis. Extensive survey was made during study period (2013-2014) Present project work has been completed at the department of botany, Sant Gadge Baba Amravati University, Amravati.

Project Sample: The flower of plant Species belonging to Malvaceae family which were more dominant in Academic year 2013-2014 were collected.

Requirement: Camera, compound microscope, dissecting microscope, slide, cover slip, foreceps, niddle, etc.

Measurement Procedure: The present work carried with parameters used for family analysis with the help of taxonomical characters of plant species, such as inflorescences, flower sepal, petals, androecium, gynoecium, fruits, etc. All this measure parameters split into its sub characters eg. Length of pedicel, bract, patal shape/colours, sepal-shape/ colour, no. of stamen, length of filament, fixation, presence or absence of hairs on filament, no. of stigma, colours of style etc.

Microscopic Examination: The microscopic examination was made under dissecting microscope as well as compound microscope. The examination was made on the floral parts and photographs were taken by the camera. The temporary slides prepared for androecium and T.S of ovary was for characters identification and slides were examined using compound microscope under 10X magnification.

Drawing and sketches: The drawing and sketches of plant specimens under investigation was worked out by using point 0.5 ink pen. A minute detail of plant species was recorded in drawing and sketches. This observation was not covered in the photography.

\section{Observations:}

In the survey, the plant flower belonging to the family- Malvaceae- Abelmoschus esculentusL. Abelmoschus manihot L. Gossupium hirsutum L. Hibiscus rosa-sinensis L. Hibiscus cannabinus L. Sida rhombifolia L. were collected from the University campus of Sant Gadge Baba Amravati University, Amravati. For the study of floral variation different floral variation, different floral features are considered, these are inflorescence, pedicel, bract, androecium, gynoecium, etc. All these characters which are helpful in determination of floral variation are mentioned in following observation table.

\section{Result and discussion:}

The present study was undertaken with a view to elucidate the variations and morphological characters of a flower of Malvaceae family. The variations in the floral morphology are distinctly observed in flowercalyx(Aestivation, sepal condition), corolla( aestivation, shape, colour), androecium Thecas,Fixation, Filament Length, Direction of anther, Colour), Gynoecium(number of ovule and locule, style length,shape and colour, stigma shape, length and colour and modification such as presence of hairs). It is in agreement with some of the earlier research finding of Danier (1960) and Hutchinson (1958) where as the others added data for easy identification and classification of these taxa. This data from floral morphology of Malvaceae family, however present some important character that could be exploited in improving the characterization of Malvaceae family. 
Table 1.- Floral characteristics of family Malvaceae plants collected from study area

\begin{tabular}{|c|c|c|c|c|c|c|c|}
\hline $\begin{array}{l}\mathbf{S} \\
\mathbf{r} . \\
\mathbf{N} \\
\mathbf{0}\end{array}$ & $\begin{array}{l}\text { Floral } \\
\text { characters }\end{array}$ & $\begin{array}{l}\text { Abelmoschus } \\
\text { esculentus }\end{array}$ & $\begin{array}{l}\text { Abelmoschus } \\
\text { manihot }\end{array}$ & $\begin{array}{l}\text { Gossupium } \\
\text { hirsutum }\end{array}$ & $\begin{array}{l}\text { Hibiscus } \\
\text { rosasinensi } \\
s\end{array}$ & $\begin{array}{l}\text { Hibiscus } \\
\text { cannabinus }\end{array}$ & $\begin{array}{l}\text { Sida } \\
\text { rhombofolia }\end{array}$ \\
\hline \multirow{3}{*}{1} & $\begin{array}{l}\text { Common } \\
\text { Name- }\end{array}$ & Bhindi & Ran Bhindi & Kapas & Chinarose & Ambadi & Lajvanti \\
\hline & Habitat- & Terrestrial & Terrestrial & Terrestrial & Terrestrial & Terrestrial & Terrestrial \\
\hline & Habit- & Under shrub & Herb & Herb & Shrubs & Shrubs & Herb \\
\hline 2 & Inflorescences & $\begin{array}{l}\text { Solitary } \\
\text { axillary }\end{array}$ & $\begin{array}{l}\text { Solitary } \\
\text { axillary }\end{array}$ & $\begin{array}{l}\text { Solitary } \\
\text { axillary }\end{array}$ & $\begin{array}{l}\text { Solitary } \\
\text { cyme }\end{array}$ & Solitary axillary & $\begin{array}{l}\text { Solitary } \\
\text { axillary }\end{array}$ \\
\hline \multirow[t]{4}{*}{3} & Flower & Complete & Complete & Complete & Complete & Complete & Complete \\
\hline & Pedicel length & $1.2-1.4 \mathrm{~cm}$ & $2.3-4 \mathrm{~cm}$ & $2-3 \mathrm{~cm}$ & $3-4 \mathrm{~cm}$ & $2-3 \mathrm{~cm}$ & $0.1-0.3 \mathrm{~cm}$ \\
\hline & Shape & Ovate & Campanulate & Obviate & Ovate & Companulate & Ovate \\
\hline & Length & $5-6 \mathrm{~cm}$ & $3-5 \mathrm{~cm}$ & $5-6 \mathrm{~cm}$ & $6-8 \mathrm{~cm}$ & $3.5-4 \mathrm{~cm}$ & $1.5-2 \mathrm{~cm}$ \\
\hline \multirow[t]{5}{*}{4} & Calyx (sepal) & Present/5 & Present/5 & Present/5 & Present/5 & Present/5 & Present/10 \\
\hline & Aestivation & Valvate & Valvate & Valvate & Quincancial & Imbricate & Valvate \\
\hline & Colour & Green & Green & Green & Green & Green & Green \\
\hline & $\begin{array}{l}\text { Sepal } \\
\text { condition }\end{array}$ & $\begin{array}{l}\text { Gamosepalou } \\
\text { s }\end{array}$ & Polysepalous & $\begin{array}{l}\text { Gamosepalo } \\
\text { us }\end{array}$ & $\begin{array}{l}\text { Gamosepalo } \\
\text { us }\end{array}$ & Gamosepalous & $\begin{array}{l}\text { Gamosepalou } \\
\text { s }\end{array}$ \\
\hline & Duration & Persistant & Coducus & Persistant & Persistant & Persistant & Persistant \\
\hline \multirow[t]{4}{*}{5} & Corolla (petal) & Present/5 & Present/5 & Present/5 & Present/5 & Present/5 & Present/5 \\
\hline & Aestivation & Twisted & Imbricate & Imbricate & Twisted & Twisted & Valvate \\
\hline & Shape/colour & $\begin{array}{l}\text { Cuculiform/p } \\
\text { ale yellow }\end{array}$ & $\begin{array}{l}\text { Cuculiform/w } \\
\text { hitish yellow }\end{array}$ & $\begin{array}{l}\text { Cuculiform } \\
\text { /Yellow }\end{array}$ & $\begin{array}{l}\text { Trumpet/Re } \\
\text { d }\end{array}$ & $\begin{array}{l}\text { Campanulate } / \mathrm{P} \\
\text { ale yellow }\end{array}$ & $\begin{array}{l}\text { Campanulate } \\
\text { / Pale yellow }\end{array}$ \\
\hline & $\begin{array}{l}\text { Petal } \\
\text { condition }\end{array}$ & Polypetalous & Polypetalous & $\begin{array}{l}\text { Polypetalou } \\
\mathrm{s}\end{array}$ & Polypetalous & Polypetalous & Polypetalous \\
\hline \multirow[t]{9}{*}{6} & Androecium & Present $/ \infty$ & Present $/ \infty$ & Present $/ \infty$ & Present $/ \infty$ & Present $/ \infty$ & Present $/ \infty$ \\
\hline & Theca's & Dithicous & Dithicous & $\begin{array}{l}\text { Monuthicou } \\
\text { s }\end{array}$ & Monuthicous & Monuthicous & Dithicous \\
\hline & Fixation & Dorsifixed & Basifixed & Dorsifixed & Dorsifixed & Dorsifixed & Dorsifixed \\
\hline & $\begin{array}{l}\text { Filament } \\
\text { Length }\end{array}$ & $2.2-2.5 \mathrm{~mm}$ & $0.1-0.5$ & $0.4-0.6 \mathrm{~cm}$ & $0.4-0.5 \mathrm{~cm}$ & $1-2 \mathrm{~cm}$ & $1.5-1.8 \mathrm{~cm}$ \\
\hline & $\begin{array}{l}\text { Direction of } \\
\text { anther }\end{array}$ & Extrose & Extrose & Extrose & Extrose & Extrose & Extrose \\
\hline & Condition & Polyandrous & Polyandrous & $\begin{array}{l}\text { Monadapho } \\
\text { us }\end{array}$ & Polyandrous & Polyandrous & Polyandrous \\
\hline & Filament & Steminoid & Steminoid & Steminoid & Steminoid & Steminoid & Steminoid \\
\hline & Modification & alternate & alternate & alternate & alternate & alternate & alternate \\
\hline & Colour & Pale yellow & Yellow & Yellow & Faint pink & Yellow & Yellow \\
\hline \multirow[t]{14}{*}{7} & Gynoecium & $\begin{array}{l}\text { Pentacarpellar } \\
\text { y }\end{array}$ & $\begin{array}{l}\text { Pentacarpellar } \\
\text { y }\end{array}$ & $\begin{array}{l}\text { Monocarpell } \\
\text { ary }\end{array}$ & $\begin{array}{l}\text { Pentacarpell } \\
\text { ary }\end{array}$ & Pentacarpellary & $\begin{array}{l}\text { Pentacarpellar } \\
\text { y }\end{array}$ \\
\hline & No.of Ovule & 10 & 10 & 8 & $8-10$ & $5-10$ & $5-6$ \\
\hline & No. of locule & 5 & 5 & 4 & 5 & 5 & 1 \\
\hline & Placentation & Axile & Marginal & Marginal & Marginal & Marginal & Marginal \\
\hline & $\begin{array}{l}\text { Ovary } \\
\text { position }\end{array}$ & Superior & Superior & Superior & Superior & Superior & Superior \\
\hline & A)Style & Present/1 & Present/1 & Present/1 & Present/1 & Present/1 & Present/ 1 \\
\hline & Shape & Cylindrical & Cylindrical & Geniculate & Cylindrical & Elliptical & Cylindrical \\
\hline & Length & $0.5-1 \mathrm{~cm}$ & $0.5-1 \mathrm{~cm}$ & $3-4 \mathrm{~cm}$ & $4-5 \mathrm{~cm}$ & $3-5 \mathrm{~cm}$ & $0.3-0.4 \mathrm{~cm}$ \\
\hline & Colour & Brown & Faint green & Faintyellow & Faint red & Pale yellow & Yellow \\
\hline & B)Stigma & Present/5 & Present/5 & Present/ 1 & Present/5 & Present/5 & Present/5-10 \\
\hline & Shape & Capitate & Capitate & Sulcate & Discoid & Capitate & Capitate \\
\hline & Length & $0.5 \mathrm{~mm}$ & $0.1 \mathrm{~mm}$ & $2 \mathrm{~mm}$ & $1 \mathrm{~mm}$ & $0.1-0.2 \mathrm{~cm}$ & $0.1-0.2 \mathrm{~cm}$ \\
\hline & Colour & Dark red & Yellow & Pale yellow & Red & Red & Yellow \\
\hline & $\begin{array}{l}\text { Any } \\
\text { modification } \\
\text { on ovary }\end{array}$ & Hairs present & Hairs present & $\begin{array}{l}\text { Hairs } \\
\text { present }\end{array}$ & $\begin{array}{l}\text { Hairs } \\
\text { present }\end{array}$ & Hairs present & Hairs present \\
\hline
\end{tabular}




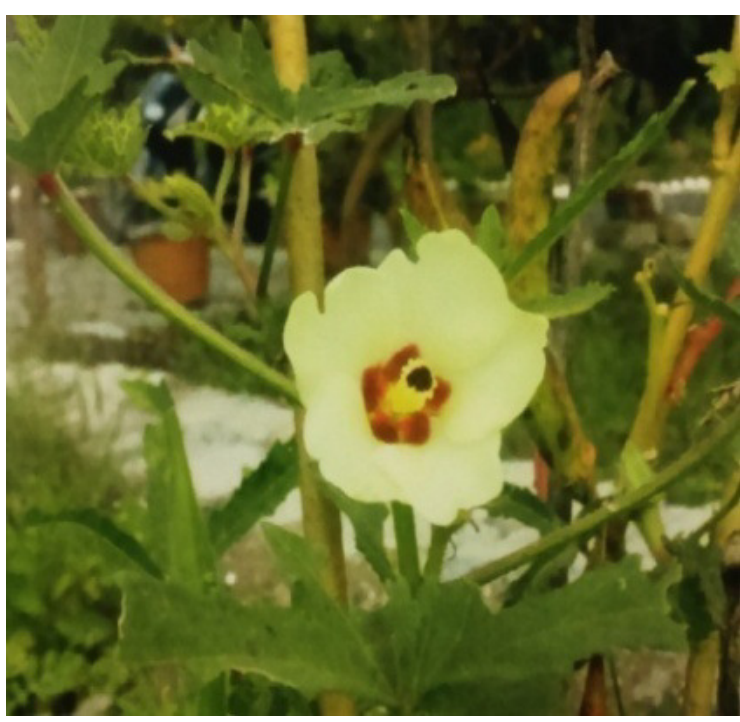

1.1 Abelmoschus esculentus L.

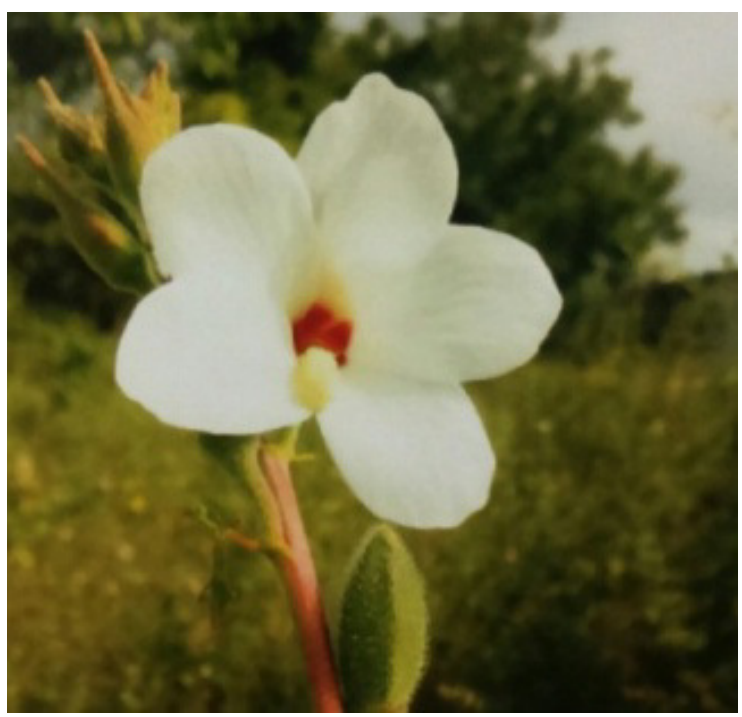

2.1 Abelmoshcus manihot $\mathrm{L}$.

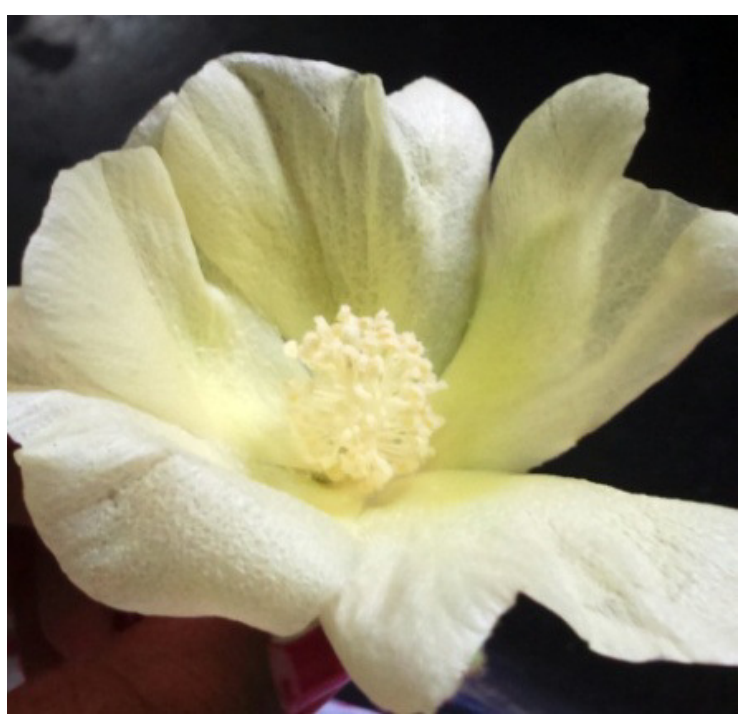

3.1 Gossypium hirsutum L.

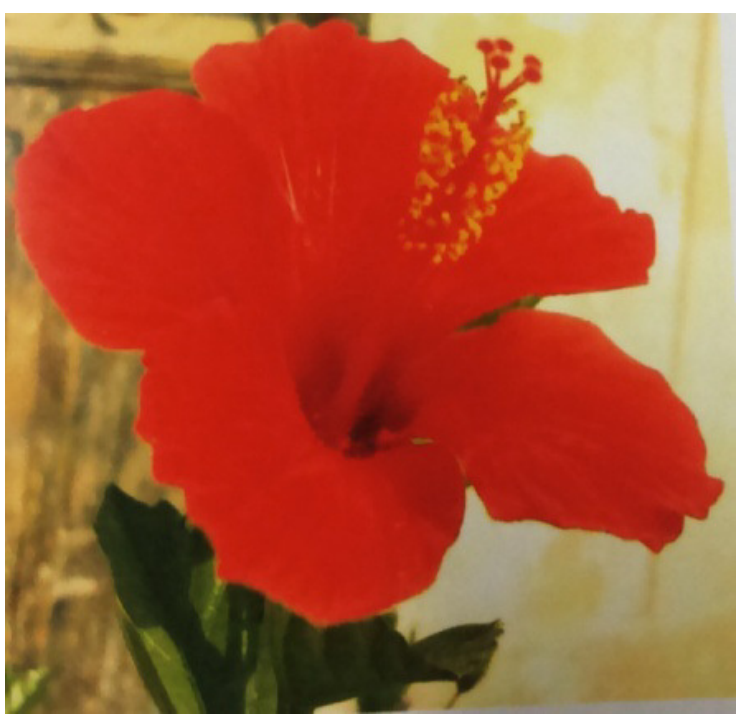

4.1 Hibiscus rosa-sinensis L.

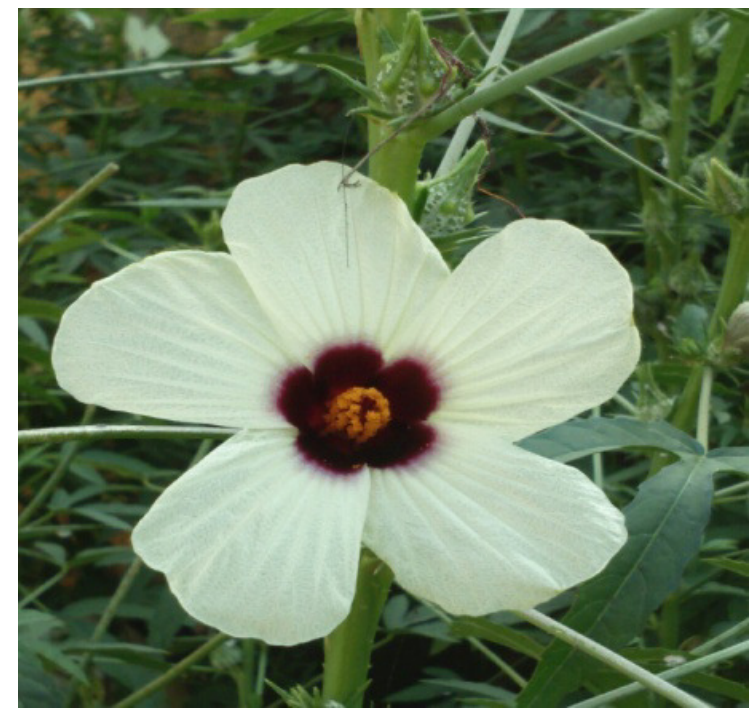

5.1 Hibiscus cannabinus L.

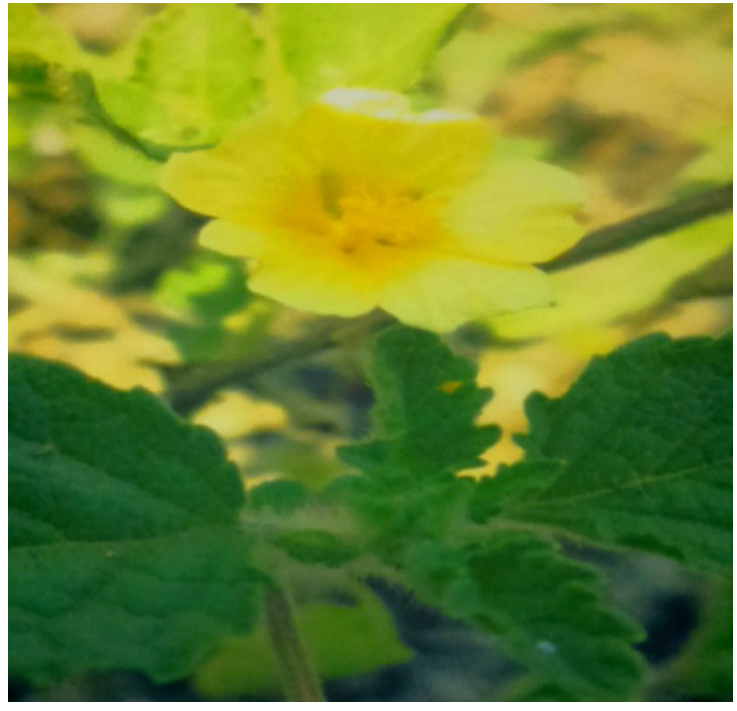

6.1 Sida rhombifolia L. 
With the help of morphological characters and this morpho technique used in this study, it is possible to distinguish between 6 species in Malvaceae family. The sunlight, water, pollinators are responsible to cause the variation in plant, the present study discussed the variation found in floral parts are different in genus and species, but in same genus it show minute variation (Aborg, 1948). It has been discussed that the floral parts such as calyxcorolla their aestivation, shape size, length and androecium-gynoecium condition, direction of anther,stigma and other modification observerd in this work are due to the action of environmental factors.

\section{Conclusion:}

The present investigation on flower characters within 6 species belonging to family Malvaceae was undertaken from Sant Gadge Baba Amravati University Campus during academic year 2013-2014. During the field survey flowers of some species were collected. From the morphological study of flower of Malvaceae family it is concluded that the existing classification of some genera is based on main characters including flower uni or bisexual, sepal and petal modification, number of androecium, shape, etc. Gynoecium are five in numbers. It shows always marginal placentation and position of ovary is different having superior characters and colours are observed in various combination. The present work showed that some characters are closely related and some are distantly related with respect to whorls of flower. Further the application of this method can elaborate taxonomical purview of the various genera and family identification in the future. The floral characters can help to resolve the taxonomic status of the family and also the identification of genera and species.

References:

Alqasoumi S.I., (2001). 'Okra' Abelmoschus esculentus L.: A study of its heptoprotective activity.

Anil Kumar and Ashatha Singh., (2012). Review on Hibiscus rosasinensis International Journal of Research in Pharmaceutical and Biomedical Sciences.(2012) Vol. 3 (2).

Junior Cezar Muneratto., (2014). THE FLORAL STRUCTURE OF THREE WEEDY SPECIES OF SIDA (MALVACEAE) . Bot. Res. Inst. Texas 8(1): 127 - 137. 2014

Richmond T. R., (2014). Gossypium hirsutum L.: The genetics of flowering response in cotton. VI. Quantitative analysis of photoperiodism of texas 86, Gossypium hirsutum race. 